\title{
An Observational Study to Assess the Validity of Anguli Pramana in the Present Era
}

\author{
Research Article
}

\section{Pratibha Visave $^{1 *}$, Deepnarayan Shukla ${ }^{2}$, Deepali Choudhari ${ }^{3}$}

1. Associate Professor, Siddhakala Ayurved College, Sangamner, Maharashtra, India.

2. H.O.D. \& Professor, Dept of Rachana Sharir, R.A. Podar Ayurved Medical College, Mumbai. 3. Associate Professor, S. S. T. Ayurved College, Sangamner, Maharashtra.

\begin{abstract}
Introduction: The concept of Anguli pramana is one of the hypothetical concepts in Ayurved put forth by acharyas. It mainly deals with the measurements of various parts of the human body. After reviewing the previous research done, it was noticed that, not a single study was being carried out by anyone of the researchers for assessing the validity of Anguli pramana in the present era. Therefore, the present study was planned. Method: After ethical clearance, the study was conducted. In total 770 participants of age group 18-50 years from Ahmednagar and Nashik region were selected. Measurements were taken for selected parameters, recorded and converted into Swa-anguli pramana. Swa-anguli pramana was measured by taking width of the middle finger at the proximal interphalangeal joint of right hand. All the measurements were taken following Standard Operating Procedure. The data was analyzed with the test of Normality, Z score using Systat 13.0 version software. Result: In the present study, obtained value and standard value stated by Acharya Charaka for the selected parameters were compared and found statistically different. Similarly, obtained value and standard value stated by Acharya Sushruta for the selected parameters were compared and found statistically different. Discussion: The results were negative i.e., non comparable with the standard values stated by acharas for the selected parameters. It was observed that the Anguli pramana mentioned in ancient literature may not be considered valid in the present era. It may be because of evolutionary changes and lifestyle changes of the human being.
\end{abstract}

Key Words: Anguli pramana, Swa-anguli pramana, Anthropometry, Measurement, Standard value, Observed value.

\section{Introduction}

Anguli pramana is a unique conceptual contribution by our sages. It was used to measure the parts of the human body. Due importance was given by Acharya Charaka to the concept of 'Sama pramana' i.e., proportionate body. (1) Anguli pramana was stated as a tool for assessing 'Ayu' (life span) of the person as well as strength and health of a person before commencing the treatment by a physician. (2)(3) This method of measurement was adopted by our acharyas thousands of years ago. They have mentioned measurements of various parts of the human body. Due to some evolutionary changes and changing lifestyles of human beings, variations can be found in human body structure. (4)(5) Anguli pramana is based on the personalized approach, where an individual's own finger width is to be used as a measuring unit. (6) This fact is useful in the current era where everything is preferred to be tailor made. Especially, when it comes to making

\section{* Corresponding Author:}

Pratibha Visave

Associate Professor,

Department of Rachana Sharir,

Siddhakala Ayurved College,

Sangamner, Maharashtra, India.

Email Id: pratibha.pps@gmail.com artificial limbs, Anguli pramana can be equally beneficial to modern Anthropometry. Acharyas have mentioned the measurements of various parts of the body. Anthropometry is a modern counterpart of ancient Anguli pramana. Considering the previous research done, it was observed that, not a single study was being carried out by anyone of the researchers for the purpose of validation of Anguli pramana in concurrence with the present era. The researcher wanted to test the neutral assumption $\left(\mathrm{H}_{0}\right)$ that the standard value and actual average value calculated both do not differ significantly. The study was based on the research question: Whether ancient Anguli pramana is valid in the present era? Hence, the present study was planned and the main purpose of the present study was to validate the Anguli pramana in the present era.

\section{Methodology \\ Study design}

The study design preferred for the present study was Observational (Survey). The measurements were taken for selected body parts and recorded on the case record form.

\section{Sampling technique}

Non-probability sampling technique was used for getting samples for the present study. The study was basically in the form of a survey where participation 
was voluntary. Those who were willing to participate were included into the study after taking their written consent.

\section{Sample size}

For the present study, 770 apparently healthy participants of age group 18-50 years from Ahmednagar and Nashik region were selected. The sample size was calculated on the basis of Census 2011 and considering $50 \%$ response rate for the survey, 5\% error margin in $95 \%$ confidence level. Rao soft tables were used for the same.

\section{Inclusion criteria}

Age group 18-50 years of both genders, same geographical region (here Ahmednagar and Nashik), same socio-economic status (middle class).

\section{Exclusion criteria}

Wheelchair bound individuals, persons having physical disability, persons who have difficulty in standing steady or straight, persons with hairstyle or turban.

\section{Materials}

For the research work, the materials utilized were stature meter, steel tape, measuring tape, digital vernier calliper, weighing machine, calculator, informed consent form, case record form.

\section{Assessment parameters}

The parameters selected for assessment were as follows,

- Swa-anguli pramana: Width of the middle finger of the right hand,

- Purush Ayam (Standing height)

- Purush Vistar (Arm span)

- Shir Parinah (Head circumference)

- Bahu Ayam (Length of arm)

- Prakoshtha Ayam (Length of forearm)

- Prakoshtha Parinah (Forearm circumference)

- Manibandha Parinah (Wrist circumference)

- Hasta Ayam (Length of hand)

- Hasta Vistar (Width of hand)

- Uru Ayam (Length of thigh)

- Uru Parinah (Thigh circumference)

- Janu Ayam (Length of knee)

- Janu Parinah (Knee circumference)

- Jangha Ayam (Length of leg)

- Jangha Parinah (Leg circumference)

- Gulpha Parinah (Ankle circumference)

- Pad Ayam (Length of foot)

- Pad Vistar (Width of foot)

- Pad Parinah (Foot circumference)

- Kati Vistar (Breadth of waist)

- Urdhwa Shakha Ayam (Length of upper extremity)

- Adho Shakha Ayam (Length of lower extremity)
After seeking ethical committee permission the study was conducted. All the measurements were taken following Standard Operating Procedure (SOP). The SOP was set using modern anthropometric techniques. (7) The data collected from the survey study was compiled, tabulated and analysed using the test of Normality, Z score. Systat 13.0 version software was used to carry out the statistical analysis of the data.

Data analysis was carried out using statistical tests viz. test of Normality for testing normal distribution of the data, $\mathrm{Z}$ score for the whole data of 770 participants. Standard values were the values quoted by acharyas whereas observed values were the values which were actually measured and noted on the case record form.

The normality of the data was tested using the Shapiro Wilks normality statistics and it was found to be normally distributed. As the sample size was very large, i.e.770 $(>500)$ and statistically the normality of the data was established, the $\mathrm{Z}$ score statistics test for single mean is applied at $95 \%$ confidence level for each actually recorded parameter. The researcher wanted to test the neutral assumption $\left(\mathrm{H}_{0}\right)$ that the standard value and actual average value calculated both do not differ significantly. The standard values were taken from the ancient literature by Acharya Charaka and Sushruta and they were separately tested with the actual calculated values. The Swa-anguli pramana was considered by measuring the width of middle finger at the proximal interphalangeal joint of the right hand of each participant. For the purpose of comparison, obtained measurements were converted into Anguli pramana. It was done by dividing the obtained measurement by Swa-anguli pramana (individual's own finger width). The calculated values obtained in terms Anguli pramana were recorded in the case record form.

To compare if there is any significant difference between average measurement of each parameter and the Anguli pramana value stated by Charaka, $\mathrm{Z}$ score statistics test for single mean was applied at 95\% confidence level for each actually recorded parameter and the results obtained are shown in Table 1. Similarly, to compare if there is any significant difference between average measurement of each parameter and the Anguli pramana value stated by Sushruta, once again $\mathrm{Z}$ score statistics test for single mean was applied at 95\% confidence level for each actually recorded parameter and the results obtained are shown in Table 2.

\section{Observations and Result}

The result embraces the statistical analysis with tabular presentation of the data and the study outcome. For this, the data collected from the survey study was compiled, tabulated and analyzed using the statistical test, Z score. 
International Journal of Ayurvedic Medicine, Vol 12 (1), 90-93

Table 1. Comparison of Actual average value with the value stated by Acharya Charaka

\begin{tabular}{|l|l|l|l|l|l|l|l|l|}
\hline No. & Parameter & $\begin{array}{l}\text { Std. } \\
\text { Value }\end{array}$ & $\begin{array}{l}\text { Actual } \\
\text { Mean }\end{array}$ & $\begin{array}{l}\text { S.D. } \\
\text { S. E. }\end{array}$ & Z Value & p Value & Remark \\
\hline 1 & Purush Ayam & 84 & 95.1395 & 8.3307 & 0.3002 & 37.1049 & 0.0000 & Significant \\
\hline 2 & Purush Vistar & 84 & 96.9567 & 7.3464 & 0.2648 & 48.9401 & 0.0000 & Significant \\
\hline 3 & Shir Parinah & 32 & 32.5926 & 2.6370 & 0.09503 & 6.2358 & 0.0000 & Significant \\
\hline 4 & Bahu Ayam & 16 & 18.7629 & 1.7834 & 0.0643 & 42.9889 & 0.0000 & Significant \\
\hline 5 & Prakoshtha Ayam & 15 & 15.6214 & 1.3647 & 0.0492 & 12.6348 & 0.0000 & Significant \\
\hline 6 & Hasta Ayam & 12 & 10.5366 & 0.8963 & 0.0323 & -45.3074 & 0.0000 & Significant \\
\hline 7 & Uru Ayam & 18 & 26.9806 & 3.0349 & 0.1094 & 82.1111 & 0.0000 & Significant \\
\hline 8 & Uru Parinah & 30 & 27.6018 & 3.4358 & 0.12380 & -19.3688 & 0.0000 & Significant \\
\hline 9 & Janu Ayam & 4 & 4.8965 & 1.8684 & 0.0673 & 13.3144 & 0.0000 & Significant \\
\hline 10 & Janu Parinah & 16 & 21.3278 & 2.5602 & 0.0923 & 57.7449 & 0.0000 & Significant \\
\hline 11 & Jangha Ayam & 18 & 21.5326 & 2.4155 & 0.0871 & 40.5817 & 0.0000 & Significant \\
\hline 12 & Jangha Parinah & 16 & 19.7282 & 2.3269 & 0.0839 & 44.4604 & 0.0000 & Significant \\
\hline 13 & Pad Ayam & 14 & 13.7273 & 1.1681 & 0.0421 & -6.478 & 0.0000 & Significant \\
\hline 14 & Pad Vistar & 6 & 5.8947 & 0.8886 & 0.03202 & -3.2885 & 0.0010 & Significant \\
\hline 15 & Kati Vistar & 16 & 23.2499 & 3.2345 & 0.1166 & 62.1971 & 0.0000 & Significant \\
\hline & & & & & & & &
\end{tabular}

From Table-1, it can be observed that there is a significant difference between the average actual value recorded and the standard value stated by Charaka for specific parameters in terms of Anguli pramana. Prakoshtha Parinah, Manibandha Parinah, Hasta Vistar, Gulpha Parinah, Pad Parinah, Urdhwa Shakha Ayam and Adho Shakha Ayam are not mentioned by Acharya Charaka.

Table 2. Comparison of Actual average value with the value stated by Acharya Sushruta

\begin{tabular}{|c|c|c|c|c|c|c|c|c|}
\hline No. & Parameter & $\begin{array}{l}\text { Std. } \\
\text { Value }\end{array}$ & $\begin{array}{l}\text { Actual } \\
\text { Mean }\end{array}$ & S. D. & S. E. & Z Value & p Value & Remark \\
\hline 1 & Purush Ayam & 120 & 95.1395 & 8.3307 & 0.3002 & -82.8086 & 0.0000 & Significant \\
\hline 2 & Bahu Ayam & 16 & 18.7629 & 1.7834 & 0.0643 & 42.9889 & 0.0000 & Significant \\
\hline 3 & Prakoshtha Ayam & 16 & 15.6214 & 1.3647 & 0.0492 & -7.6980 & 0.0000 & Significant \\
\hline 4 & Prakoshtha Parinah & 12 & 11.8834 & 1.4631 & 0.0527 & -2.2115 & 0.0271 & Significant \\
\hline 5 & Manibandha Parinah & 12 & 9.1709 & 0.7453 & 0.0269 & -105.339 & 0.0000 & Significant \\
\hline 6 & Hasta Ayam & 6 & 10.5366 & 0.8963 & 0.0323 & 140.4549 & 0.0000 & Significant \\
\hline 7 & Hasta Vistar & 4 & 4.8817 & 0.4171 & 0.0150 & 58.6532 & 0.0000 & Significant \\
\hline 8 & Uru Ayam & 18 & 26.9806 & 3.0349 & 0.1094 & 82.1111 & 0.0000 & Significant \\
\hline 9 & Uru Parinah & 32 & 27.6018 & 3.4358 & 0.1238 & -35.5216 & 0.0000 & Significant \\
\hline 10 & Janu Parinah & 14 & 21.3278 & 2.5602 & 0.0923 & 79.4217 & 0.0000 & Significant \\
\hline 11 & Jangha Ayam & 18 & 21.5326 & 2.4155 & 0.08705 & 40.5817 & 0.0000 & Significant \\
\hline 12 & Jangha Parinah & 16 & 19.7282 & 2.3269 & 0.0839 & 44.4604 & 0.0000 & Significant \\
\hline 13 & Gulpha Parinah & 14 & 13.5222 & 1.5986 & 0.0576 & -8.2938 & 0.0000 & Significant \\
\hline 14 & Pad Ayam & 14 & 13.7273 & 1.1681 & 0.0421 & -6.4780 & 0.0000 & Significant \\
\hline 15 & Pad Vistar & 5 & 5.8947 & 0.8886 & 0.0320 & 27.9413 & 0.0000 & Significant \\
\hline 16 & Pad Parinah & 14 & 13.7622 & 1.4122 & 0.0509 & -4.6728 & 0.0000 & Significant \\
\hline 17 & Kati Vistar & 18 & 23.2499 & 3.2345 & 0.1166 & 45.0390 & 0.0000 & Significant \\
\hline 18 & Urdhwa Shakha Ayam & 32 & 42.3617 & 3.2056 & 0.1155 & 89.6955 & 0.0000 & Significant \\
\hline 19 & Adho Shakha Ayam & 50 & 55.2646 & 5.0346 & 0.1814 & 29.0168 & 0.0000 & Significant \\
\hline
\end{tabular}

From Table-2, it can be observed that there is a significant difference between the average actual value recorded and the standard value stated by Sushruta for specific parameters in terms of Anguli pramana. Also, Purush Vistar, Shir Parinah and Janu Ayam are not stated by Acharya Sushruta.

\section{Discussion}

The result reveals the distribution of the study population according to gender and age. Gender wise distribution of the study population shows male participants $(36.10 \%)$ and female participants $(63.90 \%)$. Age wise distribution of study population shows the highest percentage of the age group 18-20 years (44.16 $\%)$ and the lowest percentage belonging to the $36-40$ years age group $(4.29 \%)$.

Swa-anguli pramana was taken by measuring the width of middle finger at the proximal interphalangeal joint of the right hand. It ranged from $1.29-2.48 \mathrm{~cm}$ with an average $1.69 \mathrm{~cm}$. In the present study, obtained value and standard value stated by Acharya Charaka for the selected parameters were compared which were found statistically different. (Table-1) Similarly, obtained value and standard value stated by Acharya Sushruta for the selected parameters were compared which were also found statistically different. (Table-2)

Considering the previous work done or the similar studies, it was found that, not a single study was carried out by anyone of the researchers for the validation of Anguli pramana in the present era. However, few studies recorded variation in some of the body measurements stated in ancient literature. (8)(9) $(10)(11)(12)$ These studies supported the findings of the present study. 


\section{Conclusion}

The study aimed at the assessment of validity of Anguli pramana in the present era. For this, body measurements were taken for selected parameters in all the 770 participants and noted in the case record form. The obtained measurements and standard measurements were compared separately.

The study has achieved its objective of assessment of validity of Anguli pramana. The results were negative i.e., non comparable with the standard values stated by Acharya. Each parameter was separately compared and the obtained values found to be significantly different. In brief it can be concluded that the concept of Anguli pramana mentioned in ancient literature may not be considered valid in the present era. It may be because of evolutionary changes and lifestyle changes of the human being.

\section{Scope for Further Research in the Field}

May be the sample size for the present study was not sufficient to draw any conclusion which can be made generalized. Hence, there is a pressing need of extending the research further on a very large scale, so as to generalize the concept for each population. The study can be performed in various countries with diverse ethnicities. In this way one can check the uniqueness of the ancient form of measurements and a new set of measurement values in terms of Anguli pramana can be derived for the current era.

\section{References}

1. Vaidya Yadavji Trikamji Acharya. Charaka Samhita revised by Charaka and Dridhabala with Shri Chakrapani Datta Ayurveda Dipika commentary in Sanskrit. $5^{\text {th }}$ edition. Varanasi; Choukhambha Sanskrit Sansthan; 2008. 738p

2. Vaidya Yadavji Trikamji Acharya. Charaka Samhita revised by Charaka and Dridhabala with Shri Chakrapani Datta Ayurveda Dipika commentary in
Sanskrit. $5^{\text {th }}$ edition. Varanasi; Choukhambha Sanskrit Sansthan; 2008. 739p

3. Yadavji Trikamji Acharya. Sushruta Samhita of Acharya Sushruta with Nibandha Sangraha of Dalhanacharya. $8^{\text {th }}$ edition. Varanasi; Choukhambha Orientalia; 2008. 824p.

4. ht tps://e n.wikipedia.org/wiki/ American_Journal_of_Physical_Anthropology dated 04-02-2021 time 20.54 IST

5. Gert S, Louise B. Evolutionary perspectives on Human height variation: Biological Reviews. Cambridge Philosophical Society. First published 20 Dec 2014. February, 2016; 91(1);206-234

6. Thatte D G. Sharir Rachana Vigyan. 2nd edition. Varanasi; Chaukhambha Sanskrit Series Office; 2008. 637p

7. National Health and Nutrition Examination Survey III, Body Measurements (Anthropometry), Westat Inc.1650 Research Boulevard, Rockville, MD 20850, (301) October, 1988; 251-1500

8. Bhatnagar V, Lahange S, Dhannajay. A Comprehensive Study on Standardization of Anguli Pramana w.s.r. to Pramana of Urdhva Shakha (Upper Limb). Journal of Ayurveda, Jul-Sep, 2016; $\mathrm{X}(3) ; 41-52$

9. Jain N, Yadav S, Jain T. Anthropometric study on Pramana of Uru and Jangha to disperse controversies regarding Anguli Pramana. Ojas Panchakarma, A Peer Reviewed Journal of Holistic Health Management. October, 2016; 8(7); 11-15

10. Pai R, Govindaraju U. Study on Pramana Shareera in relation to Prakriti. Journal of Ayurveda and Integrated Medical Sciences May-June, 2017; 2(3); 66-69

11. Jain N, Bhatnagar V, Lahange S. Anthropometric study of Adhah Shakha w.s.r. to Anguli Pramana described in Brihat Trayi. Journal of Ayurveda OctDec, 2017; 11(4); 70-76

12. Phule S, Patil G, Ghate U. Study of association of Charakokta Anguli Pramana with Physical fitness, International Journal of Research. June, 2019; 8(6); 5334-5343. 